\title{
Evaluation of The Role and Position of Dispute Resolution Councils in Iran's Criminal Policy in Comparison with Similar Institutions in The French Judiciary*
}

\author{
Hassan Vahedi, ${ }^{1}$ Abdolvahid Zahedi, ${ }^{2}$ Firooz Mahmoudi Janaki ${ }^{3}$ \\ 1, 2 Islamic Azad University Tehran, Iran, ${ }^{3}$ University of Tehran, Iran
}

\subsection{8/jch.v9i2.21744}

\begin{abstract}
The Dispute Resolution Council was established as a public institution in the last few decades to reduce the number of cases sent to the judiciary in Iran and strengthen public participation and increase the role of the people in criminal justice policy. Although the activities of this institution in recent years have led to a decrease in the number of cases sent to judicial institutions, but its public aspect was not fulfilled as intended. In addition, the law of this council has many contradictions with the constitution with limitations and problems in the legal and structural field that have affected its functions. However, the role of the people is significant in similar institutions in the legal system of the Common Law and France, while strengthening the participatory aspect. This issue has been an effective measure in strengthening participatory criminal policy in these countries. The purpose of this research was to investigate the criminal policy of the Dispute Resolution Council and similar institutions in France.
\end{abstract}

Keywords: Dispute Resolution Council, French Law, Iranian Criminal Justice Policy

\footnotetext{
August, 2021.

${ }^{1}$ Hassan Vahedi, PhD student in criminal law and criminology south Tehran Branch, Islamic Azad university Tehran, Iran. Email: vahedi.ha@gmail.com

${ }^{2}$ Abdolvahid Zahedi, Professor Department of criminal law and criminology, south Tehran Branch, Islamic Azad university, Tehran, Iran. Email: Zahedi.abdolvahid@gmail.com

${ }^{3}$ Firooz Mahmoudi janaki, Associate professor, Department of Criminal Law and Criminology, University of Tehran, Iran. Email: f.mahmoudi49@gmail.com

Corresponding Author: zahedi.abdolvahid@gmail.com
}

* Received: February 12, 2021, revised: April 16, 2021, accepted: June 18, 2021, Published: 31 


\title{
Evaluasi Peran dan Kedudukan Dewan Penyelesaian Sengketa Dalam Kebijakan Pidana Iran Dibandingkan dengan Institusi Serupa di Peradilan Prancis
}

\begin{abstract}
Abstrak
Dewan Penyelesaian Sengketa didirikan sebagai lembaga publik dalam beberapa dekade terakhir untuk mengurangi jumlah kasus yang dikirim ke peradilan di Iran dan memperkuat partisipasi publik dan meningkatkan peran masyarakat dalam kebijakan peradilan pidana. Meskipun kegiatan lembaga ini dalam beberapa tahun terakhir telah menyebabkan penurunan jumlah kasus yang dikirim ke lembaga peradilan, tetapi aspek publiknya tidak terpenuhi sebagaimana dimaksud. Selain itu, undang-undang dewan ini memiliki banyak kontradiksi dengan konstitusi dengan keterbatasan dan masalah di bidang hukum dan struktural yang mempengaruhi fungsinya. Namun, peran masyarakat cukup signifikan dalam lembaga sejenis dalam sistem hukum Common Law dan Perancis, sekaligus memperkuat aspek partisipatif. Isu ini telah menjadi langkah yang efektif dalam memperkuat kebijakan kriminal partisipatif di negara-negara tersebut. Tujuan dari penelitian ini adalah untuk mengetahui kebijakan kriminal dari Dispute Resolution Council dan lembaga sejenis di Perancis.

Kata Kunci: Dewan Penyelesaian Sengketa, Hukum Prancis, Kebijakan Peradilan Pidana Iran

\section{Оценка роли и позиции советов по решению спорных вопросов В уголовной политике ирана по сравнению с аналогичными учреждениями во французской судебной системе}

\begin{abstract}
Аннотация
Совет по решению спорных вопросов был создан как государственное учреждение в последние десятилетия для сокращения количества дел, передаваемых в судебные органы в Иране, и расширения участия общественности и повышения роли общественности в политике уголовного правосудия. Хотя деятельность этого учреждения в последние годы привела к уменьшению количества дел, направляемых в судебные органы, общественный аспект не выполняется должным образом. Кроме того, закон этого совета имеет много противоречий с конституцией с ограничениями и проблемами в правовой и структурной областях, которые влияют на его функционирование. Тем не менее, роль сообщества весьма значительна в аналогичных учреждениях в системе общего права и правовой системы Франции, а также в усилении аспекта участия. Этот вопрос стал эффеективным шагом в укреплении совместной уголовной политики в этих странах. Целью данного исследования является определение уголовной политики Совета по разрешению спорных вопросов и аналогичных учреждений во Франции.

Ключевые Слова: Совет по решению спорных вопросов, Французское право, политика в области уголовного правосудия в Иране
\end{abstract}




\section{A. Introduction}

Trusting in people and giving them a role in the justice system can have many benefits. On the one hand, this decision will be able to gain their trust and, on the other hand, facilitate the administration of justice. Today, governments are trying to find different solutions to rise quasi-formal, informal or nongovernmental institutions. Moreover, the role of public institutions in the legal, judicial and justice systems in some countries has been able to remove many of the obstacles in this area. Some countries have strengthened and organized applications outside of formal institutions in the legal and judicial system, as well as in crime prevention and repression to fix the shortcomings in the official systems.

From the early 19th century, the increase in legal knowledge and human criminology, along with the development of other sciences, fundamentally changed the methods of dealing with crime and crime. Various terms, such as criminal policy, which emphasized more codified, coherent, logical, and scientific programs in the fight against the criminal phenomenon, entered the field of the fight against crime. However, government and official forces continued to direct the task of combating crime by using repressive methods (Zohr, 2004: 33).

Criminal policy, according to its new concept, is a bridge between criminal law and criminology. Expanding these concepts, it can be said that criminal policy includes a set of methods by which the community council organizes reactions against the criminal phenomenon. Thus, criminal policy is synonymous with the theoretical and practical aspects of various forms of social control (crime and deviance). It is obvious that criminal law, as the core or the place of the strongest pressure and tension, has a significant presence in criminal politics. Nevertheless, criminal practices in the realm of criminal policy are no longer alone. There are other forms of social control such as non-criminal, nonrepressive and sometimes even non-governmental around them. According to this meaning, criminal policy is the applied art or strategy in the legal rules and institutions of the criminal justice system to prevent and fight crime and to correct and treat the offender (Marty, 2002: 128).

In addition, criminal policy in each country has different dimensions and aspects, which are classified into different types based on different contexts and dimensions. Criminal policy is divided into the following four types according to the tools used in the fight against the criminal phenomenon and the achievement of the desired goal and objectives: 
a. Legislative criminal policy: The tools of legislative criminal policy are law, such as the constitution, criminal law, and criminal procedure. In other words, criminal policy in the legislative stage means the laws that are passed to combat the criminal phenomenon. The legislative criminal policy is the use of the tools of law, which include the constitution, criminal law, and criminal procedure.

b. Judicial criminal policy: The basis of a country's criminal justice policy should be examined in monitoring and enforcing the laws, as well as the product of the work of the judiciary and the pillars of those who can play a role in a country's criminal policy in various ways and affect legislative criminal policy by providing appropriate judicial bills. A noteworthy point that is raised in the criminal justice policy is the issue of the independence of judges, which must be accepted that this independence along with the necessary preconditions can be a big and effective step in the criminal justice policy.

c. Executive criminal policy: The measures and ideas that the police should take against crimes are referred to as executive criminal policy (Sayyah, 1951). It is necessary to review the policies and decisions adopted by the executive branch and its pillars along with legal and judicial criminal policy in the new concept of executive criminal policy. Although the executive branch does not have criminal tools, it can play an important role in regulating criminal policy and its movement and dynamism by special supervisory levers and guaranteeing administrative performances, as well as the possibility of submitting special bills for approval in the parliament.

d. Participatory criminal policy: Today's raised question is whether the government alone can be successful in combating the criminal phenomenon? This question has led to a fourth type of criminal policy called participatory. This type of criminal policy has entered the field of combating crime (Sayyah, 1951). Efforts to involve non-governmental organizations in pursuing and controlling crimes and legal actions against criminals, as well as some economic, social, political and criminological factors, attracted the attention to the fact that civil society is involved in criminal policy programs. The design and implementation of a new trend, based on the widest and most active participation of civil society in various stages was implemented and justice was achieved. Today, this thinking is referred to as participatory criminal policy (Dispute Resolution Councils Regulations, approved in 2008). 
Although some participatory institutions such as the House of Justice and Arbitration Councils were eliminated to implement participatory criminal policy in Iran after the Islamic Revolution, and the role of civil and popular institutions in the field of judiciary and justice was diminished, the role and position of public participation in the judiciary, legal, and legislative system in the last few decades has finally increased in some matters.

Although these relevant laws and the way they were formed and operated have been criticized, the passage of this law and the formation of dispute resolution councils was an important step in the implementation of participatory criminal policy in Iran. This council has faced many ups and downs in recent years, which has had various functions. The tools and goals used by the managers and decision-makers of the society, the informal body (civil society), and the public sphere against the act by leaving the act that violates the law, are dealt with in the criminal policy. One of the most important and basic issues in this field is that these tools are different in each country. Therefore, the reasons for this difference and the motivation for choosing this approach should be considered by managers and officials of criminal policy to theorize by receiving and recognizing the useful approach and the positive effects related to it, and then to apply it in current societies (Gholami and Rahimi, 2009: 150). However, this research seeks to examine the discourse of criminal policy governing the Dispute Resolution Council and provide a more appropriate and desirable model to examine the criminal policy of France.

Considering that dispute resolution councils are considered as a body of the country's judicial system, the outcome of its performance in the judicial and legal system is very decisive. This institution has had positive functions and desirable works in the past few decades, which was criticized in many areas. The necessity of examining this council is evident in the context of the participatory criminal policy discourse of the Islamic Republic of Iran. This study, explanation, and analysis of various aspects in providing a suitable and innovative solution in resolving the shortcomings of the Dispute Resolution Council law helped to identify the differences between the law of the Dispute Resolution Council and other laws of the country and the parallel functions of the Dispute Resolution Council with other legal and judicial institutions.

\section{Research literature}

Maghsoudpour and Rezaei Moghadam (2017) conducted a research entitled "Review of the Law on Dispute Resolution Councils approved in 2015 
and its comparison with the previous regulations" examined the laws related to the Dispute Resolution Council and compared and evaluated it with previous rules and regulations. Therefore, the authors examined and criticized issues such as reviewing the competence of the Dispute Resolution Council and its types, determining the asking price in the Dispute Resolution Council and the evolution of legislation in this field, the criterion of presence and absence of council decisions and the possibility and method of protesting various decisions of the Dispute Resolution Council. Their findings regarding the status of the Dispute Resolution Council law confirmed shortcomings in this law that should be reviewed and revised after its temporary implementation and the ambiguities and shortcomings should be eliminated.

Gholami and Rahimi (2009) conducted a research entitled "Dispute Resolution Councils and review of challenges facing this institution" by explaining the characteristics of restorative justice and the need for replacing this justice with criminal justice in the country, to the challenges facing the institution, including goals competencies and the law of the council itself. They have called for special attention to be paid to restorative justice in the way it is legislated by presenting practical suggestions.

Moradi (2008) conducted a research entitled "Study of the legal competencies of dispute resolution councils by comparative study of similar institutions in jurisprudence and common law" expressed their legal and practical shortcomings by explaining similar institutions of peace, compromise and mediation in common law and Islamic jurisprudence and explaining its special functions in civil and criminal matters, in comparison with the institution of the Dispute Resolution Council in the country. Finally, they made suggestions in the administrative, selective, financial and legal areas of the institution.

Sharifzadeh (2007) conducted a paper "Study of the concept, role, and position of local community in mediation processes and the Dispute Resolution Council" considered the institution of the Dispute Resolution Council in the country with its lofty goals very different and incomparable with the local community by defining the local community as a management system of the criminal justice system, the role of the Dispute Resolution Council in mediation and peace and conciliation of disputes. They considered the need for a general overhaul of the regulations.

Dejkhah (2003) conducted a paper entitled "Study of the role of dispute resolution councils in criminal matters" examined and analyzed legal shortcomings and its violations with other laws by explaining the functions and rules of the law of the Dispute Resolution Council in the discussion of criminal 
matters and introducing the competencies of this newly established institution in criminal matters. While explaining the goals of criminal justice in the international arena, he has analyzed the privatization policies of the judiciary to reduce criminal inflation and reform the individual and society.

\section{B. METHODS}

This research has studied the subject at theoretical levels based on descriptive-analytical method. The necessary data and information have been collected in a library method using books, articles, and dissertations related to the research topic. The research was conducted by referring to the scientific works and existing documents related to the criminal policy discourse and the rules and regulations of the Dispute Resolution Council on the one hand, and reviewing and studying legal sources related to French criminal policy, and related information.

\section{RESULTS AND DISCUSSION}

\section{Criminal policy governing the Dispute Resolution Council and similar institutions in France}

Evaluation of the role and position of dispute resolution councils in Iran's criminal justice policy. Given the ultimate and fundamental goal of criminal policy in Iran, which is based on punishment, crime prevention and correction and treatment of criminals, the realization of this is within the responsibilities of the judiciary. The reason is that in paragraph 5 of Article 156 of the Constitution, appropriate action to prevent the occurrence of crime and to correct criminals is one of the main statistical duties of the judiciary. However, achieving such a goal, contrary to appearances, requires the cooperation and coordination of all relevant institutions. In the meantime, the inevitable role and mission of the executive and legislative branches in the formulation, formation, and implementation of criminal policy cannot be ignored. This issue does not negate the central duties of the executive branch in implementing the principles of the constitution, especially regarding the rights of the nation and the legislature in approving the relevant regulations (Farajiha, 1991: 42).

Considering the changes in criminal policy, it can be said that Iran's criminal policy has also benefited from this change. Iran's criminal policy underwent dramatic changes at the same time as the Islamic Revolution (Hosseini Nik, 1994: 32). The changes that took place in the political and 
governing system of Iran caused a change in the country's criminal policy. The reform of the political structure led to a change in the constitution, laws and judicial, legislative and executive structure of the country, and the enactment of new laws and regulations of criminal policy and its framework underwent changes. Challenges to the political system, as well as widespread and rapid change, have led to problems and conflicts in laws and political and social life.

After years of reforming and revising the laws and regulations, the country's criminal policy has moved to some extent out of complexity with flaws and shortcomings and to some extent towards structuring and regularization. Gradually, a new approach to criminal policy was proposed, which should consider transnational and international conditions and global factors with the extensive changes in the world system and international relations, along with the continuity of the world system and judicial, legal, legislative and international judicial and criminal law. A new approach to criminal policy was created called participatory criminal policy with the intensification of the wave of democracy and the role of the people, civil society, and guilds. This issue attracted the attention of the authorities to the role of popular and civil institutions in participating in the judicial and criminal system. As mentioned, one of the most important and fundamental issues in the criminal policy of countries is the participation of the people and popular and civil institutions and guilds in judicial affairs. The development of public participation in judicial affairs in Iran is one of the manifestations of participatory criminal policy, which is in the form of criminal policy discourse.

Therefore, one of the plans in the development of criminal policy and the creation of participatory criminal policy was the adoption of the Law on Dispute Resolution Councils in 2008. "The law of the Dispute Resolution Council is a mechanism for reconciling the offender, the victim and the civil society that is trying to achieve this important thing, namely closeness, peace and reconciliation of the parties using existing mechanisms independent of traditional criminal justice whose sole purpose is to achieve punishment." The general definition of a Dispute Resolution Council is as follows:

"The Dispute Resolution Council is a body that has the authority to consult and will act to resolve disputes and problems between them after consultation, and in accordance with the judicial powers delegated to it by the legislature and having the power to hear minor matters" (Moradi, 2008: 105).

However, significant rules and regulations can be established regarding the participation of civil society in the fight against crime due to the importance of the issue of peace and reconciliation and the recommendation to reform the 
essence of religion by religious leaders in Iran apart from customary law topics. What is remarkable is that the Iranian legislator has not only not used these principles and contexts in a desirable and complete way, but has also taken a considerable distance from the new ideas of customary law. Despite the fact that the Islamic legislature envisaged dispute resolution councils to benefit from the policies of popularizing the judiciary, this newly established institution complies with the programs and principles of participatory justice has always been discussed by legal thinkers (Hosseini, 2004).

For the past few decades, Iran has sought to expand its criminal policy in the judiciary to expand and develop the criminal justice policy and reduce the obstacles and problems faced by the judicial and judicial institutions due to the very high volume of cases and lawsuits, as well as to prevent the entry of minor cases in the judicial and criminal courts and their resolution at very low levels. This goal was created by creating a lower level of judicial courts with the intention of activating the role of people and civil institutions in its formation. This lower level of the judiciary was formed and began its activities as Dispute Resolution Council with a council approach to handle minor cases and a kind of judicial institution that is both in terms of administrative bureaucracy and of structural prestige at the local and indigenous level to handle lawsuits in the right way. According to some legal and judicial thinkers, this institution and the strength of its foundations with the activity of several years have taken an important step towards the development of participatory criminal policy in the field of judiciary. The related potential and legal capacity can be added to by removing barriers in the field of bureaucracy, structure, decision-making, and strategy and its strategies.

However, many thinkers and jurists consider the Dispute Resolution Council as a civil and public institution for the participation of the people in the judiciary. These groups believe that the establishment of an institution called the Dispute Resolution Council is rooted in legal principles. For example, the Dispute Resolution Council could be a manifestation of some constitutional principle or other relevant law. In this regard, Article 26 of the Constitution addresses two issues related to the formation of non-governmental organizations, including the principle of freedom of associations, and the principle of free participation of individuals in these communities. The presence and participation of people in NGOs in the criminal procedures in the form of Article 66 of the Criminal Procedure Code (Ramezani Ghavamabadi, 2015: 565) can also be a reason for establishing a Dispute Resolution Council as a civil institution and a step towards participatory criminal policy. 
The law on the Dispute Resolution Council and the formation of these councils was enacted and approved to achieve the defined goals. According to Article 189, the Third program of Economic, Social, and Cultural development of the Dispute Resolution Council was established to achieve two important goals: a). Reducing people's referral to the courts; b). Development of public participation.

In explaining the purpose, one of the main problems of the judiciary is the high volume of incoming judicial cases, which causes delays in the trial and overcrowding of the judiciary, resulting in public dissatisfaction. Regarding the second goal, i.e. the development of public participation, it should be said that today governments try to reduce their activities by leaving part of their work to the private sector. This is reflected not only in economic and educational affairs but also in judicial affairs. The development of public participation in judicial affairs, especially in criminal matters and under the influence of participatory criminal policy has found special effects, the most prominent of which is mediation (Fathi, 2005: 93-92).

The mediation bylaw in criminal matters explained the legislator's goal of forming dispute resolution councils in 2015 by carefully considering the regulations:

1. Creating the ground for more people's trust in the criminal justice system and the sovereignty of the country by using participatory criminal policy;

2. Better execution of justice by using and participating in popular participation;

3. Preventing the concentration of cases in judicial authorities and speeding up the resolution of disputes to enforce the rights of clients (Abbasi, 2003: $15)$.

Judging and resolving disputes in the Iranian legal system, according to Articles 34 and 156 of the Constitution, is primarily the duty of the judiciary and judges, but the concentration of judicial cases in the judiciary has led to inefficiency, inaccuracy, and delays. Therefore, the resolution of matters that are not of a judicial nature or have a lesser judicial nature was left to the Dispute Resolution Councils, which are under the supervision of the judiciary under Article 189 of the Law on the Third Economic-Social and Cultural Development Plan of the Islamic Republic of Iran, approved in 2000, and then under the Law on the Dispute Resolution Council, approved in 2008 to reduce public appeals to the judiciary and to develop public participation. Several years after the 
execution of the Dispute Resolution Council law in 2015, a new law was approved for the Dispute Resolution Council, which includes new innovations in the field of legal and criminal disputes.

The duties and powers of the Dispute Resolution Council in Article 189 of the Third Economic, Social, and Cultural Development Plan Law are: a). Resolving local disputes; b). Settlement of lawsuits without judicial nature; c). Resolving cases whose judicial nature is less complex (Fathi, 2005: 93-92).

Therefore, the Dispute Resolution Council was formed within the framework of criminal justice policy to achieve the set goals and its execution mechanisms were provided. Given the terms and conditions of existing laws and the rules and regulations regarding its structure and functions, which in some cases are contradictory. This council has not been able to function properly as it should.

According to the Law on Dispute Resolution Council, this council has two functions, in practice, each of these institutions negates the other. These functions are peace, compromise, and reconciliation. First peace and reconciliation, then criminal procedure if no result is achieved. The first function is consistent with participatory criminal policy, but the second function transforms this institution into a parallel institution with the judiciary (Rast, 2009: 257).

The Dispute Resolution Council has criminal jurisdiction in some cases, there are:

a. The council's competence to negotiate and compromise: According to paragraph 1 of Article 8 of the Executive Regulations of the Dispute Resolution Council the Council is competent to negotiate with the parties and establish peace and reconciliation between them in all forgivable crimes. In case of failure to reach an agreement between the parties, the case will be sent to judicial authorities.

1. Local competence of the Dispute Resolution Council: The local competence of the council is in the following affairs: First; the occurrence of a crime in the area of the council and the jurisdiction of the court where the crime took place; Second: Residence or employment of the litigants in the council; Third: Consent of the litigants (Dejkhah, 2003: 52).

Moreover, some authorities and competencies were approved by the head of the judiciary in the form of a circular in 2019 regarding the competencies of the Dispute Resolution Council and in relation to the subject of Article 104 of the 
Islamic Penal Code. Some of the most important of these competencies and authorities are as follows:

a. In all forgivable crimes subject to Article 104 of the Islamic Penal Code of 2013, such as insulting individuals, threatening and aggressive possession and forgivable crimes subject to other laws, the case should be sent to the Dispute Resolution Council to preserve the evidence of the crime and respect the rights of the plaintiff, public order and, if necessary, to conduct the necessary investigations, before registration in the prosecutor's office, general courts of the district or two criminal courts, to mediate and make peace and reconciliation. In case of reaching a compromise, the level of compromise between the parties and the plaintiff's pardon will be submitted to the parliament and the case will be filed in the council, in which case the prosecutor's office will not face any obligation.

b. In crimes that have both public and private aspects, the parties are referred to the Dispute Resolution Council while conducting an investigation and investigation by the judicial authorities to act in accordance with Article 24 of the Bylaws of the Dispute Resolution Councils and to reflect the result to the relevant judicial authority in case of compromise on the private aspect.

c. In all disputes and family lawsuits and other civil lawsuits: A. The case is first submitted to the Dispute Resolution Council with the encouragement of the applicant to consider the compromise and his/her consent, so that if a compromise is reached, action will be taken in accordance with the regulations. B. In case of referring to the courts, the referring authority shall refer the case to the Dispute Resolution Council before referring the case to the branch and registering that case considering Article 11 of the Law on Dispute Resolution Councils and considering the quality of the dispute or dispute and the possibility of resolving it through peace and reconciliation.

d. Judicial authorities should make every effort to take advantage of the council's capacity to mediate in executing Article 82 of the Code of Criminal Procedure.

e. The Dispute Resolution Council is obliged to fulfill the duties set forth in the Law on Dispute Resolution Councils and this circular to realize the right and with the aim that the people achieve their right in the shortest 
possible time, by using the skills and techniques of peace and reconciliation and mediation.

f. Provincial courts should establish special branches of peace and reconciliation with the help of courts and tribunals, while respecting the priority of using intellectuals, local elders, local trustees and socially influential people (with an age requirement of at least 40 years old) to make peace and conciliation cases through optimal and maximum use of the existing capacities of Dispute Resolution Councils or, if necessary, in coordination with the Center for Dispute Resolution Councils.

g. The Judiciary's Deputy for Human Resources is obliged to hold special courses on dialogue and problem-solving skills with the help of experienced professors for council members.

h. The Strategic Deputy is obliged to provide the necessary facilities, equipment and credit to pay the remuneration of the members and staff of the council in coordination with the Center for Council Affairs to optimally implement this directive.

i. The responsibility for supervising the proper implementation of the provisions of this circular rests with the Chief Justices of the provinces (Circular of the Dispute Resolution Council regarding Article 104 of the Islamic Penal Code, ISNA, 2019.

\section{Comparison of Iran Dispute Resolution Council or similar institutions in France}

France is also one of the countries with a long history of legal and judicial system. The country has differences in terms of judicial and legal structure with countries such as the United Kingdom and the United States, whose legal and judicial structures are somewhat interdependent. In addition, the country has made great progress in the field of criminal policy, especially participatory criminal policy and judicial criminal policy. In the following, we will examine the judicial system of France and similar institutions of the Dispute Resolution Council in this country.

\section{The judiciary and similar institutions of the Dispute Resolution Council in France and its governing criminal policy}

France, unlike English-speaking countries that follow the common law system, has its own domestic legal system and civil law. The common law system has evolved over the years and is largely based on consensus and jurisprudence. 
Civil rights systems, on the other hand, are largely based on a set of rules. The French judiciary is independent of the legislature (government) based on the French Constitution in line with the democratic principle of separation of authorities. The judiciary consists of the Constitutional Council, district courts, judicial and administrative courts (in the three branches of the Court of First Instance, the Court of Appeal, and the State Council), Appellate Court, the Police Court, and the local courts, respectively.

\section{a. Constitutional Council}

The Constitutional Council is the highest constitutional institute in France. This institution was established on October 4, 1958 by the Constitution of the Fifth Republic and its duty is to ensure the observance of the principles and provisions of the Constitution. This institution oversees statutes before ratification, as well as overseeing national elections and answering citizens' questions about the constitution. The Constitutional Council consists of nine members. Three are appointed by the President, three by the head of the National Assembly and three by the Speaker of the Senate. Its main task is to rule on the conformity of the laws in question with the constitution after they have been approved by parliament and before they are signed and become law by the president.

\section{b. Judicial courts and administrative courts}

These courts have jurisdiction to handle civil, criminal and administrative lawsuits. These courts are themselves divided into different sub-branches. Appellate Courts are in this category. These courts are subdivided into civil and criminal courts at lower levels of jurisdiction.

1) The civil procedure of private persons shall be heard by a district court or a local or administrative court, depending on the subject matter and the importance of the case.

2) Everyday crimes and petty criminal matters are generally dealt with by district courts or police courts.

Administrative courts are also presided over by the state council. These courts hear cases involving the French government, local authorities or other public authorities governed by public law.

\section{c. Police courts and local courts}

Police courts and local courts are at the lowest level of the French judicial hierarchy. These courts have jurisdiction over both legal and civil cases. These 
courts deal with the vast majority of minor and limited case cases. These courts exist in many areas and individuals and people can easily turn to them to settle lawsuits. These courts will immediately review the case after reviewing and confirming that the case is within their jurisdiction depending on the case. In cases where the subject of the lawsuit and the petition are beyond their competence, they refer the case to the middle levels of the judicial structure.

The police courts and the local courts are at the bottom of the pyramid of the French judicial structure. Police courts are based on the powers and responsibilities of the country's police in the past. Local courts have been set up to hear minor criminal, legal, and civil cases.

The next article examines the police court and the local court as similar bodies to the Dispute Resolution Council in Iran. These institutions act similarly to the Dispute Resolution Council in Iran due to their structure and functions, although this type of court in this country has a much longer history than the Dispute Resolution Council in Iran.

The figure below shows the judicial structure of France and the hierarchical pyramid of this power.

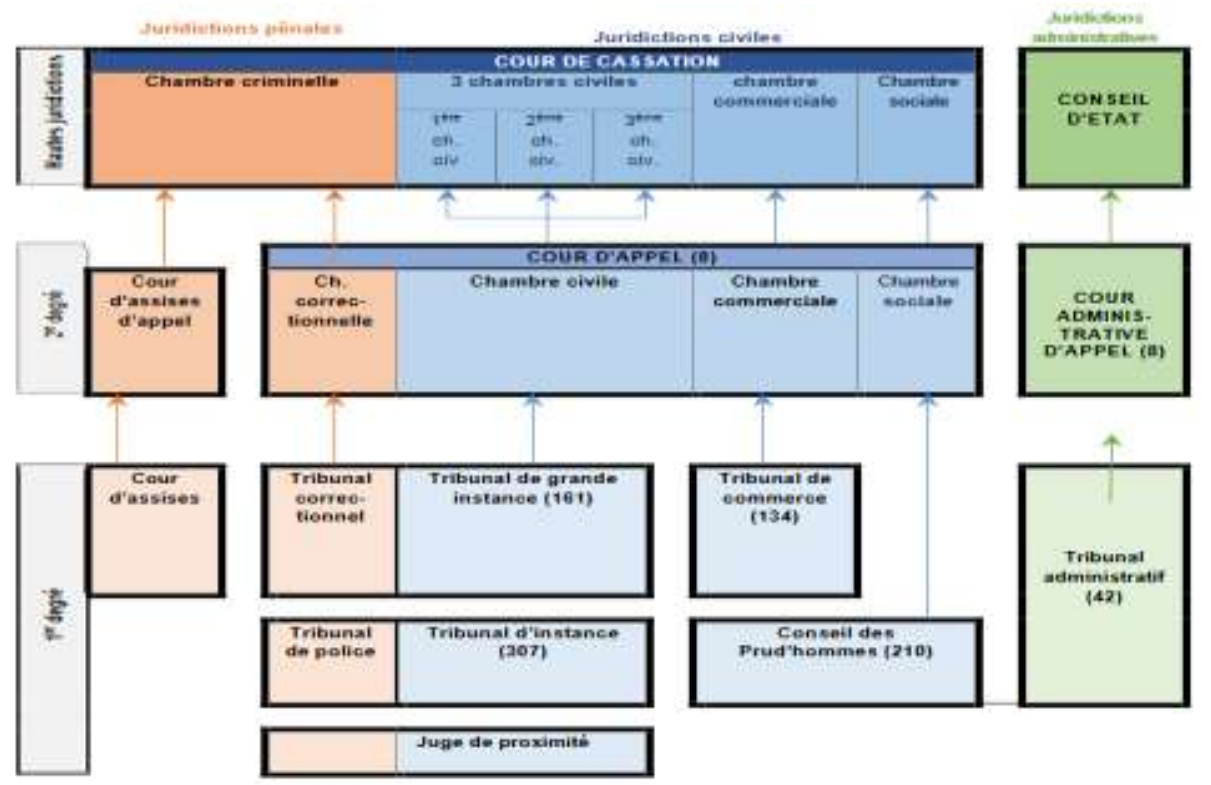

Figure 1. French judicial structure 


\section{Police courts and local courts as similar institutes to the Dispute Resolution Council}

At the bottom of the pyramid of the French judiciary are police courts and local courts. These courts have more limited authorities and duties than their superior courts and judicial institutions. However, many lawsuits are filed and numerous cases are considered in these courts. These courts are somewhat similar to the Dispute Resolution Council in terms of structure, objectives, and functions, with the difference that the history of such institutions in France is much longer than the history of the Dispute Resolution Council in Iran. The authority and scope of authority of these institutions is somewhat greater than the scope of authority and competence of the Dispute Resolution Council in Iran due to the antiquity of these institution.

\section{a. Police courts}

Police courts are at the bottom of the criminal justice system in the French judicial hierarchy that deal with criminal cases and are empowered to hear criminal cases. Restrictions are defined are defined on their authority and these courts have jurisdiction to hear specific cases. If a lawsuit or case is referred to them beyond their jurisdiction, they should refer it to a higher authority. The police court handles criminal cases at specific levels. These courts deal with all criminal offenses except those that require imprisonment or fines in excess of $€$ 4,000 . The police tribunal also has jurisdiction over commercial matters and customs claims.

\section{b. Local court}

The local courts are also the lowest courts in the hierarchy of the French judiciary in the branch of civil courts, which handle civil cases and jurisdiction over civil claims has been delegated to them. These courts also have limitations beyond which any case or lawsuit referred to them must be referred to a higher court. These courts are available in different states of the country, and the people of this country can easily file their lawsuits in these courts. These courts have a large number of cases pending and are in the process of being handled based on their performance and background, as well as the authority given to them. Due to these powers, these courts have prevented a large number of local and regional cases from entering higher courts.

There are usually several judges in local courts and police courts. The number of judges in these courts usually varies according to the volume of lawsuits and cases. There are more judges in some courts where the number of lawsuits is high, while in others a single judge is sufficient. However, despite the 
multiplicity of judges, only one judge will decide in these courts. These judges are usually experienced, professional, and trained.

\section{The purpose of establishing police courts and local courts in France}

The police force in France has long played a very important role in detecting crimes, prosecuting criminals, making decisions and resolving lawsuits in some cases. This responsibility has long been the responsibility of the French police. Gradually, an institution called the police courts has been established to structure their duties and powers with the formalization of these duties and authorities. In addition to these courts, local courts were established to expedite the litigation process, the division of local cases and lawsuits, as well as to reduce the litigation process in police institutions, which took up a lot of time for police agencies and police forces.

Other factors in the formation of local courts have been the reduction of cases submitted to higher courts, the reduction of costs for litigants, and the shortening of the litigation process. These courts have jurisdiction over cases and claims in which the subjects and disputes are less than $€ 10,000$. These courts are among the courts to which the number of cases referred is very high. The main function of these courts is to handle small civil disputes and litigation in everyday life. Other jurisdictions of these courts include litigation related to traffic accidents, disputes related to the payment of property costs, unpaid debts, claims for damages or repayment of products or services. Family litigation is also one of the jurisdictions of these courts.

These courts have been able to prevent a large number of cases from entering the higher levels of the judiciary, and many cases are processed and closed in the same courts due to their high ability to handle cases.

\section{Alternative Dispute Resolution (ADR) System in France}

Unlike other European countries, as well as countries subject to common law, the use of alternative dispute resolution methods in France has a very long history. The history of using these methods in this country dates back to two centuries ago. Alternative Dispute Resolution (ADR) methods in France are regularly promoted by authorities and legal scholars as a means of reducing the burden on the courts and resolving disputes in a faster, simpler, and cheaper way. In fact, there is a long tradition of resolving alternative disputes in France. This has caused the tendency to use these methods to always exist in this country. 
One of the most important of these methods is arbitration (Gaillard \& Jenny, 2000: 1). In addition, mediation is another method, although it is not as popular as arbitration in this country.

\section{a. Arbitration in France}

The French constitution, civil, and criminal law specially emphasize on the subject of arbitration in litigation. The importance of arbitration in the laws of this country and the great emphasis on using this method to resolve disputes has played an important role in the popularity of France as a place for arbitration. French arbitration law has long been considered a model for other countries. French law gives legal assurance to the parties to the dispute that their agreement will be based on the arbitration procedure and the outcome.

Even before the arbitration law was amended in January 2011, the French Arbitration Act was one of the freest arbitration laws in the world under the 1981 Act. The new law of 2011 seems to reinforce this fact even more. No discussion of arbitration in France would be complete without reference to the passage of French Decree No. 2011-48 of January 13, 2011, which in the past modernized the French Arbitration Act in the 1980s into the French Code of Civil Procedure, which is a positive and forward step in the arbitration performance of this country (Phillips, 2012: 1).

\section{b. Mediation in France}

Contrary to the issue of arbitration in France, which has a long history in the laws and regulations of this country in both formal judicial institutions and civil and popular institutions, mediation is a new approach and method in this country. France's experience with criminal mediation dates back to the late 1980s, and it is the practice of prosecutors and court presidents in some cities. This purely judicial initiative was gradually emphasized by the Department of Letters and Regulations. Finally, it gained legal status with the law of July 4, 1993 regarding the reform of criminal procedure (Raufian Naeini and Ebrahimi, 2019: 104).

However, the constitutional, civil, and criminal constitutions, as well as the judiciary, courts, and even the culture of France, have largely embraced arbitration. Even the many concerted efforts to encourage mediation in France over the past decade to incorporate this practice into litigation have had limited success. The nature of the civil law system in France has given some resistance to the use of mediation. Resistance to mediation is something that affects French 
society, not only the legal community and the judiciary, but also the French people. For example, the have also resisted the notion of third-party involvement in resolving labor disputes (Phillips, 2012: 1).

However, the system of alternative dispute resolution methods, and in particular the arbitration method in France, could play a good role in litigation and legal, civil and judicial cases. However, this method has been able to be raised among the people and the judiciary, and many cases have been resolved in terms of mediation, despite the resistance against it in recent years.

\section{CONCLUSIONS}

According to previous topics and conducted studies related to the criminal policy governing the Dispute Resolution Council and similar institutions in France, it can be said that the criminal policy of France is common in some principles, goals, and strategies, and different in some other cases. These institutions, which have almost similar functions, have been established based on the procedures and legal structure of countries, rather than on theoretical and scientific foundations and some structures and institutions or some of their features and functions are similar in some of these countries, following other countries or following a common legal system. For example, institutions similar to the Dispute Resolution Council in France are very different from those in common law countries. All these institutions in these countries have a different structure and strategy than the institution of the Dispute Resolution Council in Iran. However, similarities can also be observed in the comparative study of these institutions.

As another example, the establishment and formation of police courts and local courts in France is the result of the long history of the police and its active role in detecting crime, prosecuting criminals and delinquents, and investigating crimes, and its applicability to crime investigation. Therefore, the establishment of such institutions in France is the result of the traditional system and the historical background of such institutions and their positive and constructive effect on resolving disputes and conflicts.

In other words, institutions similar to the Dispute Resolution Council in France are the result of local and traditional laws and regulations and traditional judicial procedures, which have been expanded according to their desirable and significant function. Today, they operate in the form of formal judicial institutions and under special protections. Conversely, this is not the case with the Dispute Resolution Council in Iran. This council is the result of the criminal 
justice policy whose purpose was to control the volume of cases and preventing delays in the procedure in the judiciary. Such institutions in France have been the result of ancient judicial traditions and practices in accordance with existing laws and regulations. The establishment of the Dispute Resolution Council in Iran is in a different situation from France, so that this institution is neither rooted in traditional and local laws, nor subject to the supreme laws and regulations of the country.

\section{REFERENCES}

Rast, Alireza (2009), "Dispute Resolution Council and Judge Tahkim: A Shaky Step towards Participatory Criminal Policy", Journal of Legal Research, Spring and Summer, Special Issue 1.

Dejkhah, Leila (2003), "Study of the role of dispute resolution councils in criminal matters", Journal of Jurisprudence and Family Law (Nedaye Sadegh), No. 30 , Summer.

Raufian Naeini, Hamid and Ebrahimi, Shahram (2019), "Analysis of the Mediation Institution, Comparative Study of Iranian and French Law", Quarterly Journal of Private and Criminal Legal Research, No. 39, Spring.

Farajiha, Mohammad and Shahbazinia, Mohammad (2016), Abstract of the International Conference on Restorative Justice and Crime Prevention, Tarbiat Modares University, Faculty of Law.

Ramezani Ghavamabadi (2015), “A Comparative Study of the Legal Status of Non-Governmental Organizations in Iran and France; From Establishment to Activity", Quarterly Journal of Comparative Legal Studies, Volume 6, Number 2, Fall and Winter.

"Dispute Resolution Council Circular on Article 104 of the Islamic Penal Code, ISNA (2019)," Dispute Resolution Council "circular was issued by the head of the judiciary", Iranian Students News Agency.

Maghsoudpour, Rasoul and Rezaei Moghadam, Mehrdad (2017), "Study of the Law on Dispute Resolution Councils approved in 1994 and its comparison with previous regulations", Quarterly Journal of Khorasan Bar Association, Volume 7, Number 16, Winter. 
Gholami, Ali and Mohammad Mehdi Rahimi (2009), Dispute Resolution Councils and the Challenges of this Institution, Journal of Legal Discourse, Nos. 15 and 16.

Moradi, Yaser (2008), "Assessing the Legal Jurisdiction of the Dispute Resolution Council through a Comparative Study in British Law", Gawah Research Journal, No. 23, Spring.

Moradi, Yaser (2008), A Study of the Legal Competencies of Dispute Resolution Councils with a Comparative Study of Similar Institutions in Jurisprudence and Common law, Govah Legal Journal, No. 12.

Sharifzadeh, Ali (2007), A Study of the Concept, Role and Position of the Local Community in Mediation Processes and the Dispute Resolution Council, Journal of Crime Prevention Studies, Second Year, No. 2.

Fathi, Hojjatollah (2005), "Critique and Review of Dispute Resolution Councils", Quarterly Journal of Jurisprudence and Law, No. 4.

Hosseini, Seyed Mohammad, (2004) Criminal Policy in Islam and in the Islamic Republic of Iran, First Edition, Samat Publications, Tehran.

Zohr, Howard, (2004) Restorative Justice, translated by Gholami, Hossein, first edition, Majd Publications, Tehran.

Abbasi, Mostafa, (2003) Mediation in Criminal Affairs, Daneshvar Publications, Tehran Payez.

Delmas Marty, may (2002) The Great Systems of Criminal Policy; Translated by Dr. Aberandabadi, Mizan Publishing.

Hosseini Nik, Seyed Hossein (1994) Crisis in Iranian criminal policy; Master Thesis, Supervisor: Dr. Ali Hossein Najafi Aberandabadi, Islamic Azad University.

Sayyah, Ahmad (1951) Comprehensive Arabic-Persian Culture, Volume One, Lithography, Tehran

The official website of the Solving Council

Phillips, F. Peter (2012), France: Current State of Arbitration and Mediation, business conflict management, Arbitration Conflict Resolution Europe Mediation, June 4, 2012. 
http://www.businessconflictmanagement.com/blog/2012/06/francecurrent-state-of-arbitration-and-mediation/

Gaillard, Emmanuel \&Edelstein, Jenny (2000), MEDIATION IN FRANCE, Dispute Resolution Journal, Vol. 55, No. 4. https://arbitrationlaw.com/library/mediation-france-dispute-resolutionjournal-vol-55-no-4 